\title{
DOES MERGING IMPROVE EFFICIENCY? A STUDY OF ENGLISH UNIVERSITIES
}

\author{
Maria Papadimitriou \\ Lancaster University Management School, Lancaster University, Lancaster LA1 4YX \\ Email: m.papadimitriou@ lancaster.ac.uk \\ Jill Johnes ${ }^{1}$ \\ Professor of Production Economics, Huddersfield Business School, University of \\ Huddersfield, Queensgate, Huddersfield HD1 3DH \\ Email: j.johnes@hud.ac.uk
}

February 2017

Revised August 2017

\begin{abstract}
This paper focuses on the effect of merger on university efficiency. In a first stage analysis efficiency scores of English universities are derived for a 17-year period using the frontier estimation method data envelopment analysis. A second stage analysis explores the effect of merger and other factors on efficiency. We find that mean efficiency for the sector has varied from around $60 \%$ to $70 \%$, but that the efficiency levels of the vast majority of individual higher education institutions (HEIs) are not significantly different from each other. Merged HEIs have efficiency which is around 5 percentage points higher postmerger than non-merging HEIs holding all else constant; but we find that the efficiency impact of merger does not last long (not more than a year) after the merger. The transitory nature of the efficiency gain is an important finding which should be noted by politicians and managers considering a policy of merger.
\end{abstract}

Acknowledgements: We are grateful for comments to the participants of: the North West Doctoral Training Centre Conference, Liverpool, May 2015; the $13^{\text {th }}$ International Conference on Data Envelopment Analysis, Braunschweig, August 2015; and 2 anonymous referees. The work of this paper was supported by the Economic and Social Research Council, UK [grant number ES/J500094/1]

Keywords: Mergers; Higher education; Efficiency

\footnotetext{
${ }^{1}$ Corresponding author
} 


\section{Introduction}

Austerity measures continue to put pressure on public funding in England meaning that the English higher education (HE) sector is under pressure since the government subsidises both teaching ${ }^{2}$ and research. There has been speculation that funding cuts can be absorbed by efficiency savings (Mandelson 2009) which might be achieved to some extent by the closure or merger of some universities (Browne 2010; Griffiths 2010; Baker 2011; Matthews 2011; Jump 2014). This suggestion is based on efficiency theory which predicts that units will merge when they believe that they can be run more efficiently and effectively together than separately (Curri 2002; Harman and Harman 2003; Aarrevaara et al. 2009; Bösecke 2009). Any benefits of merger accrue to the owners (Bösecke 2009), which, in the context of higher education, means lower public funding requirements. Yet little is known empirically of the factors underlying efficiency in higher education and, in particular, whether merging is indeed a driver of efficiency.

There are two basic approaches to the evaluation of efficiency: the cost function approach and the production function approach. The cost function approach is concerned with how a given output set can be produced at as low a cost as possible. It requires the estimation of a cost function from observed data on costs and outputs. Any university which has costs above the estimated cost function is deemed to be cost inefficient, and frontier estimation methods exist to allow us to calculate a measure of relative efficiency of such universities, while the parameters of the function allow us to estimate whether or not there are economies of scale or scope in the sector (see Johnes and Johnes 2013 for more details). Any possibility of economies of scale would mean that merger might result in efficiency benefits.

The production function approach considers the relationship between the outputs of universities and the inputs used to produce them. Universities which produce inside the production frontier (i.e. lower than the maximum possible output from the given inputs) are deemed to be technically inefficient, and frontier estimation methods allow us to calculate a measure of relative technical efficiency for each university (see Johnes 2004 for more details). Technical efficiency is generally less well explored in the context of higher education.

In this paper we will take a production function approach. This has an advantage that by considering the physical inputs (such as students entering the university) and relating these to the outputs (such as graduates from the institution), we can take into account negative aspects of the production process (such as student non-completion which varies considerably between English institutions $)^{3}$. A cost function, by relating financial costs only to outputs, makes no such satisfactory allowance. Since a merger might have a

\footnotetext{
${ }^{2}$ Although students in England currently pay fees of just over $£ 9000$ per annum, this is largely done using loans and it has been estimated that $20 \%$ to $25 \%$ of loans taken out by students will not ultimately be repaid (http://wonkhe.com/the-wire/rab-charge-official-estimate-falls-to-20-25/). Thus university teaching is still subsidised to a considerable extent from public funds indirectly through non-repayment of loans and directly through the subsidy of the costly subjects.

${ }^{3}$ Details on non-continuation can be found here

https://www.hesa.ac.uk/component/content/article?id=2064.
} 
detrimental effect on the production process in a university, this is an important consideration.

In addition we use the non-parametric method of data envelopment analysis (DEA) to estimate efficiency. The advantages of DEA relative to a parametric frontier estimation method such as stochastic frontier analysis (SFA) are that it does not require a functional form, or explicit distributional assumptions for the inefficiency terms (Post et al. 2002), and so there are no problems or biases arising from misspecification; it can easily handle a production situation with multiple inputs and multiple outputs; and it does not require input or output prices. On the downside, DEA efficiency scores can be sensitive to the specification of the model (in terms of inputs and outputs), and to outliers. In addition, in its basic form there are no tests of statistical significance. We therefore take care with the model specification and employ bootstrapping methods in order to make the estimation more robust (Simar and Wilson 2007).

The purpose of this paper is to explore the efficiency of English higher education institutions (HEIs), and to investigate, using a second stage analysis, all the factors underlying efficiency including merger activity. To this end we use a 17-year panel of data which includes 28 incidences of merger to estimate efficiency over time and to build a panel data model of the factors relating to efficiency.

This study is distinctive for several reasons:

a) We include all possible determinants of efficiency in the second stage analysis in order to isolate the effect of merging.

b) Our data set has observations on universities both pre- and post-merger. This allows us to explore in more detail the evolution of effects of merger on efficiency.

c) The extensive panel data set allows us to use panel data estimation methods in the second stage to correct for unobserved heterogeneity in the English higher education sector.

The paper is in 6 sections of which this is the first. A review of the literature on efficiency in English HE is provided in section 2 along with findings from previous studies of the effects of merger on efficiency. Section 3 outlines the methodological approach undertaken in this paper, while section 4 presents the data and variables used in the analyses. Results are reported and interpreted in section 5. The paper ends with section 6 which draws conclusions and policy implications from the work.

\section{Efficiency and mergers in higher education: A literature review}

There is now a considerable literature concerning the technical efficiency of HEIs, and this has been extensively surveyed (Worthington 2001; Johnes 2004; De Witte and López-Torres 2015; Johnes 2015; Thanassoulis et al. 2016). Early studies of technical efficiency in UK HE focused on individual departments such as accounting (Tomkins and Green 1988), chemistry and physics (Beasley 1990; 1995), economics (Johnes and Johnes 1993), and business schools (Doyle et al. 1996), or departments within a university (Sinuany-Stern et al. 1994). More recently DEA has been applied at the institution level 
to produce measures of efficiency for all HEIs in the sector (Athanassopulos and Shale 1997; Flegg et al. 2004; Glass et al. 2006; Johnes 2006; Flegg and Allen 2007a; 2007b; Johnes 2008; Flegg and Allen 2009; Johnes 2014). These studies differ in terms of the time period covered, model specification (i.e. inputs and outputs), returns to scale assumed, and the HEIs included in the analysis. The earlier studies concentrate on a particular sub-sector of HEIs and find that, on average, efficiency is remarkably high with average technical efficiency levels between around 0.80 and 0.95. Later studies which extend the data set to include the complete HE sector which we observe in the UK today, find a wider range in mean technical efficiency at around 0.75 to 0.95 .

There is also a considerable history of using DEA to measure universities' efficiency in countries other than the UK (useful summaries can be found in Johnes (2004) and more recently in De Witte and López-Torres (2015)). A similarly wide range of efficiency values can be found from under 0.70 to well over 0.90 (Ahn et al. 1989; Ahn and Seiford 1993; Breu and Raab 1994; El-Mahgary and Lahdelma 1995; Ng and Li 2000; Avkiran 2001; Abbott and Doucouliagos 2003; Johnes and Yu 2008; Ng and Li 2009; Nazarko and Šaparauskas 2014; Andersson et al. 2017). As with studies from the UK, it is difficult to make comparisons between these studies which examine diverse HE systems, and use different samples and approaches. Generally speaking, we can expect higher mean efficiencies from studies based on small samples over a short time period and a variable returns to scale assumption than from those with considerably larger samples and applying constant returns to scale.

These studies represent interesting snapshots of the efficiency of the English or other higher education sectors in particular time periods. None, however, examines what factors might affect the underlying efficiencies, and this a serious weakness. If we know the factors which are likely to improve the technical efficiency of HEIs then policy can attempt to create the favourable conditions to achieve greater efficiency. One obvious issue on which there is a dearth of evidence is the effect which merging universities is likely to have on subsequent efficiency.

A merger ${ }^{4}$ is a formal agreement defined as: 'two or more partners combining to create a single institution, which may retain the name and legal status of one of them or be an entirely new legal entity.' (HEFCE 2012 p11). In a recent survey of university vicechancellors in the UK, $56 \%$ of vice-chancellors responding to the survey were reasonably or very confident that the UK would see significant rationalisation through HEI mergers and takeovers over the subsequent 5 to 10 years (Boxall and Woodgates 2014). But while policy has increasingly pointed to HEIs specialising in their comparative strengths such as research or teaching (Glass et al. 2006), very little work of a statistical nature has been undertaken to evaluate the impact on efficiency of mergers in higher education. ${ }^{5}$

\footnotetext{
${ }^{4}$ A HEI can engage in various forms of relationship with other HEIs, ranging from 'soft' activities such as shared purchasing and services, through joint ventures, alliances and federations, to full merger at the 'hard' end of the spectrum (Lang 2002; Harman and Harman 2008; Berriman and Jacobs 2010; HEFCE 2012). Each of these may have an effect on efficiency but the less formal relationships and collaborations are more difficult to identify, and hence their effect on efficiency is more difficult to assess.

${ }^{5}$ Instead case studies focus on the consequences of merger on the personnel, students, culture and identity of the merging institution. These studies cover a variety of countries such as: the UK (Arbuthnott and Bone
} 
Economic theory suggests that there should be efficiency benefits from merger brought about by increasing returns to scale and scope. Increasing returns to scale occur if physical input per unit of output falls as output rises. Thus administrative activity can be spread over larger output requirements (Fielden and Markham 1997; Patterson 2000; Kyvik 2002; Norgård and Skodvin 2002; Green and Johnes 2009; Ripoll-Soler and DeMiguel-Molina 2014), buildings and/or sites can be shed leading to lower maintenance (Fielden and Markham 1997; Teixeira 2007), small duplicate programmes across separate HEIs can be eliminated from all but one HEI and concentrated in the remaining university (Skodvin 1999), and so teaching staff can be spread over more students (Fielden and Markham 1997). Findings on economies of scale in the UK higher education context vary depending on the underlying data. Studies which focus on pre-1992 universities find evidence of significant economies of scale for the typical university (Glass et al. 1995a; 1995b; Johnes 1996; 1998). Later studies using data across both pre- and post-1992 HEIs find that scale economies are close to constant or decreasing for the typical university (Johnes 1997; Izadi et al. 2002; Johnes et al. 2005; Johnes et al. 2008; Johnes and Johnes 2009), but that increasing returns are observed in smaller HEIs (Johnes and Johnes 2016).

Increasing returns to scope might arise from producing teaching and research jointly, or from producing teaching (or research) across disciplines. There might be additional benefits experienced from merging, for example, expanding a HEI's academic portfolio of programmes through merger can have benefits in terms of increasing student demand because of greater diversity and variety of degree programmes (Harman 2000; Harman and Meek 2002; Kyvik 2002; Harman and Harman 2003; Teixeira 2007); this in turn might therefore lead to diversity in the student population of the institution (Harman and Harman 2003), and improve the scope of education for those students (Aarrevaara 2007). Evidence on economies of scope in UK HE is mixed but the studies which include the widest range of institutions consistently find global diseconomies of scope for the typical university (Johnes 1997; Izadi et al. 2002; Johnes et al. 2005; Johnes et al. 2008; Johnes and Johnes 2009; 2016).

There may, of course, be reasons why merger might cause greater inefficiency. First, there may be decreasing returns to scale caused by increased resource use if greater centralization increases bureaucracy or if the merging institutions are geographically distant (Curri 2002). Second, a reduction in the number of HEIs in the sector inevitably leads to greater sector concentration which, by lowering competitive pressures, could lead to lower technical efficiency of HEIs (De Fraja and Valbonesi 2012). Third, there may be a reduction in efficiency if there is a loss of quality in the teaching experience enjoyed by students (and academics) (Tight 2011). Fourth, consolidation can lead to a reduction in diversity and choice between institutions - indeed a merger might intend to reduce duplication of programmes across HEIs in order to increase technical efficiency. Reducing this choice might be socially undesirable because of the negative impact on student access caused by imperfect geographical mobility amongst students

1993; Skodvin 1999; Brown and Humphreys 2003; Cartwright et al. 2007; Locke 2007); Belgium, the Netherlands, Germany, Norway, Sweden (Skodvin 1999), Finland (Skodvin 1999; Aula and Tienari 2011; Puusa and Kekäle 2013); South Africa (van Vuuren et al. 2010); Australia (Gamage 1993; Skodvin 1999; Curri 2002; Harman 2002; Hatton 2002; Mildred 2002); China (Chen 2002; Wan and Peterson 2007). 
(Kelchtermans and Verboven 2010; De Fraja and Valbonesi 2012). It should be noted that the DEA model specification used in the subsequent analysis evaluates efficiency relating only to the first two of these points. Quality effects may be reflected by, for example, increased non-completion, and we use a production function approach to capture this. Further quality effects are accommodated in the second stage analysis.

Some rare quantitative analyses of the efficiency effects of mergers can be found in the context of Chinese higher education where there have been more than 400 mergers since the 1990s (Cai and Yang 2015). Merging has been found to have a positive effect on efficiency and productivity in the first year after merger but not in the subsequent year (Hu and Liang 2008; Mao et al. 2009). In addition a recent study of English higher education uses a panel of data from 1996/97 to 2008/09 to compare the mean technical efficiency (estimated using both SFA and DEA) of merged institutions (of which there are 19 instances) with mean efficiencies of pre- and non-merging institutions. Average efficiency is considerably higher among merged than pre-merger and non-merging institutions: the null hypothesis of identical means in the three groups is rejected in all cases (Johnes 2014).

These results should be treated with caution for a number of reasons. First, examination of the average effects of merger conceal differences in the experiences of the different partners (Stewart 2003; Johnes 2014). In some cases, both partners enjoy unambiguous efficiency gains; in others, one partner gains while the other does not; and in still other cases, efficiency declines over time for both partners (Johnes 2014). Second, it is difficult to separate the effect of the act of merging from other underlying characteristics of the merged institutions. Universities which merge, especially if the decision to merge is a bottom-up institution-level one rather than a top-down directive, are likely to have different characteristics from those which do not merge, and these characteristics could themselves cause the observed differences in efficiency. Third, effects of merger may take time to be experienced and no study has looked at the evolution of efficiency over the periods following merger. Fourth, merger and efficiency might not exhibit a simple one-way causality (merger leads to greater efficiency), but may display a more complex, two-way relationship whereby merger might lead to greater efficiency, but efficiency (or lack of it) might also be a motivation for merger. This has implications for the appropriate estimation approach. Finally, looking only at merger as the possible cause of changes in average efficiency may lead to omitted variable bias in the results if there are other factors which might also be affecting efficiency. Possible other factors are considered below.

Differences in mission (such as subject mix or concentration on third mission activities) not taken into account in the DEA model may well affect the estimated efficiencies. In England we have a diverse sector of HEIs which can be broadly split into 3 groups: pre1992 universities - traditional institutions which offer degree programmes across the academic subject spectrum and an established research mission; post-1992 HEIs institutions which have a balanced portfolio offering degree programmes across a range of academic and vocational subjects and a growing research mission; and former colleges of higher education - institutions which have been awarded university status since 2003, which might be small and specialist, and often lack a strong research mission. Evidence 
from production studies suggest that the former colleges of higher education have higher technical efficiency than the other two types (Johnes 2008; 2014); but this result is reversed in the context of cost function studies where they are found to be the least cost efficient of the three types (Johnes et al. 2005; Johnes et al. 2008; Johnes and Johnes 2009; Thanassoulis et al. 2011; Johnes and Johnes 2013).

Sources of funding might also affect efficiency; evidence from the USA suggests that reliance on tuition revenue has a negative effect on operating efficiency (Sav 2013) while government funding has a positive effect on both operating efficiency and cost efficiency in public universities (Sav 2012; 2013), but a negative effect on cost efficiency in private universities (Sav 2012). However the funding systems for higher education in the USA and England are different; mean proportion of income derived from government sources in the USA is 0.3 ( $\operatorname{Sav} 2012 ; 2013$ ). It is therefore difficult to predict the direction of the effect in English higher education. The increased competitive pressures caused by receiving a lower share of income from government sources (and hence a greater share from student fees, for example) might increase efficiency suggesting a negative relationship between proportion of funding from government and efficiency as has already been observed in the wider European higher education context (WolszczakDerlacz 2014).

It is clear that there is little empirical evidence to date in the English HE context on the factors likely to affect technical efficiency, including merger activity, and this represents a gap in the literature which this study aims to fill.

\section{Methodological approach}

We address in this study two main questions regarding the efficiency effects of merger:

1. Does the act of merging in higher education (holding all else constant) improve subsequent efficiency?

2. What is the time path over which any efficiency effects evolve?

The analysis is designed to answer these questions and is performed in two stages (Kjekshus and Hagen 2007; Kwoka and Pollitt 2010). In the first stage, bootstrapped DEA efficiency scores are derived for English HEIs. The second stage investigates the possible determinants of efficiency.

\subsection{First stage}

We use DEA to assess the technical efficiency ${ }^{6}$ of English universities in the first stage of this analysis. An underlying assumption of production analysis is that technology is

\footnotetext{
${ }^{6}$ Technical efficiency of HEI $i(i=1, \ldots, n)$ is defined as $T E_{i t}=\frac{\sum_{m=1}^{M} a_{m t} y_{m i t}}{\sum_{k=1}^{K} b_{k t} x_{k i t}}$ where $y_{m i t}$ denotes output $m(m=1, \ldots, M)$ produced by HEI $i$ at time $t(t=1, \ldots, T) ; x_{k i t}$ denotes input $k(k=1, \ldots, K)$ used by
} 
constant for the period over which the production relationship is being estimated. Over a long period of time, this assumption is questionable. We therefore address the issue of time as follows. We estimate the DEA model assuming a common production frontier over time (i.e. common technology throughout the study period). ${ }^{7}$ In the second stage we include time dummies (see next section) to allow for efficiency differences, caused by technology change, over time.

We use a constant returns to scale (CRS) DEA model as the resulting efficiency score incorporates inefficiencies due both to size of operations and managerial competence, and efficiency benefits from merger may arise from either of these.

\subsection{Second stage}

Let us denote the efficiency score of HEI $i$ in time $t$ estimated in the first stage by $T E_{i t}$. In the second stage we are interested in the following relationship:

$T E_{i t}=f\left(z_{1 t}, z_{2 t}, \ldots, z_{j t}\right)$

Where $z_{1 i t}, z_{2 i t}, \ldots, z_{j i t}$ represent a set of explanatory variables which might possibly affect the efficiency with which a HEI can convert its inputs into outputs. The data therefore form a panel comprising English HEIs in each year of the study period and this has the advantage that we can use in the second stage dedicated panel data estimation methods which correct for unobserved heterogeneity across institutions (such as quality). This analysis employs a random effects estimation method for two reasons: the number of parameters to be estimated is far less than for a fixed effects model, thus preserving both degrees of freedom and information; and it yields estimates of all coefficients including those of time invariant explanatory variables. The latter is a particularly important point given that we are interested in the effects of characteristics such as merger and university types which would not be estimated using fixed effects. The model estimated is specified as

$T E_{i t}=\alpha+z_{i t} \beta+v_{i}+\varepsilon_{i t}$

$v_{i}+\varepsilon_{i t}$ is the residual.

$v_{i} \sim \operatorname{IID}\left(0, \sigma_{v}^{2}\right)$ is the time-invarying unit-specific residual

$\varepsilon_{i t} \sim \operatorname{IID}\left(0, \sigma_{\varepsilon}^{2}\right)$ is uncorrelated over time

$z_{i t}$ is the matrix of $k$ explanatory variables (not including a constant), discussed in the next section

$\alpha$ is the intercept term denoting the mean of the unobserved heterogeneity

HEI $i$ in time $t ; \alpha_{m t}$ is the weight applied to output $m$ in time $t$; and $b_{k t}$ is the weight applied to input $k$ in time $t$. The weights are calculated for each HEI by maximizing efficiency subject to two constraints: a) the weights must be non-zero; b) the weights must be universal. For a more detailed presentation of the DEA methodology please see Coelli et al. (2005).

${ }^{7}$ We could assume from the outset that the production frontier changes over time and conduct the DEA within-year, thereby allowing for technology change over time. The caveat of this approach is that the smaller sample size can bias the efficiency scores upwards compared to the pooled estimation approach. Johnes (2014) finds that the pooled-DEA is preferable to within-year estimation because the resulting efficiencies are closely correlated with those derived from alternative parametric methods of estimation. 


\section{Data and model specification}

\subsection{First stage}

The input and output variables are constructed from annual statistics for all HEIs in England published by the Higher Education Statistics Agency (HESA). The data cover a period of 17 academic years from 1996/97 to 2012/13. The sample is an unbalanced panel of data for various reasons. Some 28 mergers have taken place in HE sector during the study period. Once a merger occurs, the merged HEI is treated as a completely new entity and allocated a new identity code (Cuesta and Orea 2002; Johnes 2014). ${ }^{8}$ In addition four HEIs are removed entirely from the sample: Open University is removed because of its large size and unique nature of teaching provision; the University of London (Institutes and activities) is also excluded on the grounds that the composition of the component HEIs recorded under this umbrella have changed over time; University of Buckingham is deleted because it is not publicly funded, and Heythrop College because it only became publicly funded during the time period under consideration. The number of HEIs included in each year therefore varies from 138 in the academic year (1996/97) to 125 in the academic year (2012/13), so the panel totals 2197 observations.

In general terms, HEIs are seen to use labour, capital and 'raw materials' to produce teaching, research and third mission activity and we specify the inputs and outputs to align with this general model. Five measures of inputs are specified. The number of fulltime equivalent (FTE) undergraduates (UGINPUT) and the number of FTE postgraduates (PGINPUT) represent the institution's raw materials. An absence of published quality measures means that these are not adjusted for quality - and we return to this issue below. The number of FTE academic staff (STAFF) and expenditure on administration and central services (ADMIN) represent academic and non-academic labour inputs respectively. Finally, capital inputs are measured by expenditure on library, computing and other learning resources (ACSERV).

Three outputs are included in this model. The number of undergraduate first degree qualifications (UGOUTPUT) and the number of postgraduate degree qualifications (PGOUTPUT) represent teaching output. These are not adjusted in any way for quality. Research output is reflected by income received from research grants and contracts (RESEARCH). It should be noted that all variables measured in monetary terms are deflated to 2012 values.

Our specification requires further discussion. First, the inclusion of students on both the input and the output sides of the function reflects the fact that there is non-completion in the higher education system and that this varies across HEIs. Second, a potential drawback of the model is the lack of quality measure particularly on teaching inputs and outputs. The random effects estimation model applied in the second stage addresses this issue as it takes into account unobserved heterogeneity from all sources including quality

\footnotetext{
${ }^{8}$ A list of HE mergers in the UK HE sector can be found here https://www.hesa.ac.uk/content/view/2884/141/.
} 
differences which are likely to vary between HEIs but to remain relatively stable over time.

Third, it should be noted that the academic staff variable includes only staff on full-time or part-time contracts. Casual staff are not included in this measure, and the extent to which their use varies by university is unknown. This should therefore be borne in mind when interpreting the results, although the panel data estimation method applied in the second stage is likely to capture, at least to some extent, any persistent heterogeneity from this context.

Fourth, the use of research income to measure research output has been questioned on the premise that it is an input rather than an output. The justification for using such a measure to reflect research output is threefold. First it is a current measure of a university's research reputation and quality since research grants are competitively won and hence reflect current research potential (whereas publications and citations, which might be considered more appropriate reflections of research output, are inevitably backwardlooking in nature). Second it is easily available and is generally accepted as a reflection of research output. Third it is typically highly correlated with publications and citations measures (Johnes and Johnes 2013).

Finally, we do not include a measure of third mission activity in our first stage model. While the HE Business and Community Interaction Survey produced by HESA provides a vast array of data from which measures of universities' third mission activity might be constructed, the data are only available from 2008/09 onwards. In line with all previous studies of technical efficiency in HE we are unable to include a measure of this output in the DEA model.

Full definitions of the first stage inputs and outputs are provided in appendix 1, while descriptive statistics for the inputs and outputs used in the DEA are presented in Table 1. On average, over the study period, HEIs produce more than 1000 graduates from postgraduate degrees, over 2500 graduates from undergraduate degrees and just over $£ 72$ million in research. These are produced from nearly 2000 postgraduate students, 7000 undergraduates, 850 FTE staff, $£ 19$ million spent on administration and $£ 10.5$ million on academic services. The large size of the standard deviations relative to means for our input and output measures is an indication of the diversity across the HEIs in the data set (see Daraio et al. 2011 for more on the diverse nature of the UK HE sector).

Table 1 here

According to figures 1 and 2 there is a general upward overall trend with respect to both inputs and outputs over time. The plateauing of research output since 2009/10 is likely a consequence of the effect of the financial crisis on public expenditure. This pattern is mirrored by a similar plateauing of administrative (though not academic) input over a similar period. Thus financial constraints caused by the financial crisis appears to have impacted administrative more than academic input.

Figures 1 and 2 here 


\subsection{Second stage}

\section{a) Merger}

The effect of merger is assessed in several distinct ways. First, a simple pre-merger, postmerger and non-merging distinction is made by including two dummy variables (PREMERGER and POSTMERGER respectively). PREMERGER takes the value 1 for HEIs which will merge (in all time periods prior merger), and zero otherwise; POSTMERGER takes the value 1 for HEIs which have merged (in all time periods following merger), and zero otherwise. The comparison group is therefore non-merging HEIs. For reasons previously outlined, we are unsure, a priori, of the direction of the relationship between POSTMERGER and efficiency.

In a separate model we investigate the possibility that efficiency effects from merger vary over time by including the pre-merger dummy (PREMERGER) combined with dummy variables to reflect the year of merger (MERGERt) and each of the four years following the merger (MERGERt+1, MERGERt+2, MERGERt+3 and MERGERt+4), respectively. Finally we investigate the possibility that efficiency prior to merger might also differ over time and include (instead of the pre-merger dummy, PREMERGER) separate dummy variables for three, two and one year prior to merger (MERGERt-3, MERGERt-2 and MERGERt-1), respectively.

\section{b) Other explanatory variables}

First, subject differences between universities are not reflected in either teaching or research outputs. It is possible that they are accounted for (at least to some extent) by the DEA estimation method which allows each unit to be assessed relative to others with a similar input-output mix. Thus universities should not be disadvantaged by being different. In addition, the random effects panel data estimation method allows for timeinvariant unobserved heterogeneity between HEIs including subject mix differences. We further explore the possible effect of the subject mix of universities on their estimated efficiency in several possible ways. First we include the ratio of number of students undertaking medicine and veterinary studies to the total number of FTE students (MEDICINE). One hypothesis is that these courses are longer and more resourceintensive; therefore a HEI with a relatively large number of this type of students might appear less efficient than others. A competing hypothesis is that these students are often the most academically able with high entry scores, their degree programme is highly vocational, and these factors might in turn have a positive effect on degree completion and performance. Thus a relatively high number of students in these subjects might have a positive effect on technical efficiency.

Second, the composition of the student body might be expected to affect efficiency. In particular, a high proportion of overseas students might permit greater opportunities for subsidisation of research, and this in turn might lead to greater measured efficiency in our model than would otherwise be the case. On the other hand, overseas students can require greater resources to mentor through the English higher education system, and could therefore be negatively related to efficiency. 
Third, we include HEI type dummies to represent pre-1992 HEIs (PRE1992) and post1992 HEIs (POST1992) which are measured relative to the base group of former colleges of HE. These are intended to reflect differences in mission both in terms of outputs produced (research, teaching or third mission) and/or in terms of subject mix. In some models we split the pre-1992 group of universities into Russell group HEIs ${ }^{9}$ (RUSSELL) and other pre-1992 HEIs (OTHERPRE1992) as the former have a strong research mission.

The precise effect of HEI type on efficiency is difficult to predict a priori. Pre-1992 (and especially Russell group) HEIs might be involved in more resource-intensive activities and hence their efficiencies might appear low. On the other hand, these are the universities which are likely to attract the highest quality inputs and hence have the greatest success at transforming inputs into outputs.

Fourth, funding sources have been found to be important in determining university efficiency and productivity (see, for example, Bolli and Somogyi (2011)). We include here the proportion of income from the government in the form of funding body grants (GOVT) in order to check whether or not source of funding affects efficiency. Previous research suggests that this might have a positive effect on efficiency in the USA (Sav 2012; 2013), but negative in a European context (Wolszczak-Derlacz and Parteka 2011).

We include the total number of FTE students (and its square) to examine whether efficiency is related to the size of the university. The square is included to assess whether the relationship is non-linear. The relationship between size and efficiency is open to debate. On the one hand, increasing returns to scale would suggest that the relationship should be positive and there is evidence to support this in the context of European higher education (Wolszczak-Derlacz and Parteka 2011; Wolszczak-Derlacz 2014). However, some studies find no relationship between size and efficiency (Bonaccorsi et al. 2006); other studies (of British universities) find mixed results with size having a positive relationship with efficiency in some years, but the converse being observed in others (Flegg et al. 2004); and there is evidence of a negative relationship between size and efficiency in Swedish HE (Daghbashyan 2011). Cost function studies also suggest constant or decreasing returns to scale in English HE (Izadi et al. 2002; Johnes and Johnes 2009; Thanassoulis et al. 2011).

Finally we include in the main analysis time dummies to allow for shifts in the frontier over time. Previous studies have found increases in productivity in the English HE (Flegg et al. 2004; Johnes 2008; 2014).

Full definitions of all the variables in the second stage analysis are provided in Appendix 2. Descriptive statistics for the second stage variables can be found in table 2. These confirm the diversity observed in the English higher education sector. For example, while the typical HEI has nearly 9000 students, this varies from under 300 to nearly 36000.

Table 2 here

\footnotetext{
${ }^{9}$ The current Russell group universities can be found here: http://russellgroup.ac.uk/about/ouruniversities/.
} 


\section{Results}

\subsection{First stage}

Over all HEIs and across all years, mean overall technical efficiency is at its lowest in 1999/00 at 0.58 and peaks in 2011/12 at 0.71 (see figure 3 ). ${ }^{10}$ On average, therefore, there appears to be scope for some efficiency improvement in the sector. At the bottom end, these results are a little lower than previous findings for the English HE sector which are also based on DEA (Johnes 2014); and also lower than those for HE sectors other than England or the UK. However, the mean values towards the end of the period are not out of line with efficiency scores estimated across a similarly diverse set of English universities, using CRS DEA, but over different time periods (Johnes 2008; 2014). We should be cautious of making comparisons both with the same HE sector at different time periods, and, particularly, across HE sectors. DEA estimates a deterministic frontier and performance of observations is relative to those in the current data set. Compared to other studies, here we use a different input-output specification, have a relatively large sample size and diversity amongst observations, and, most importantly, cover a much longer time period; we would therefore expect the results to be on the low side.

The strong upward trend in efficiency since 2008/09 (with the exception of the final year) is especially noteworthy and might reflect a response to the austerity measures following the global financial crisis - the slower growth in administrative input following 2008/09, for example, might be part of this response. But the drop in the final year might indicate that continuing to reap such efficiency gains is unsustainable.

Figure 3 here

A histogram of the mean efficiency over time for each HEI is plotted in figure 4 . At the top end, there are 10 HEIs with efficiencies in the range 0.9 to 1 , and two of these are fully efficient with respect to overall technical efficiency over the period. The worstperforming HEI, in contrast, has a mean overall technical efficiency of 0.214 , and there are 13 HEIs with a mean overall technical efficiency below 0.5. At the bottom end, there are potentially large savings in efficiency to be made.

Figure 4 here

From a managerial and policy point of view we need to know whether these differences between HEIs represent real (or significant) differences. The bootstrapping estimation method allows us to calculate for each efficiency score a $95 \%$ confidence interval. This represents an interval for each HEI within which we are $95 \%$ confident that the true efficiency lies. We can plot the efficiency scores and accompanying confidence interval, shown in figure 5 for each HEI in 2012/13. The line of mean efficiency for that year (0.69) is superimposed on to the plot. It is clear that the intervals of all but 4 HEIs at the lower end of performance overlap the mean efficiency. This suggests that, on the whole, differences between HEIs in estimated efficiency are not significant: HEIs with the highest apparent efficiency scores are not significantly different from those with lower

${ }^{10}$ Results are based on bias-corrected CRS DEA efficiencies derived using bootstrapped estimation. 
efficiency scores, with the exception of the lowest performing HEIs. Previous findings for the English and UK HE sectors have also suggested considerable overlap in performance across HEIs, although there are apparent distinctions between both the bestand worst-performing HEIs (Johnes 2014). It is worth noting that HEIs with apparently low levels of efficiency are characterised by being small and specialist and this result is similar to findings derived from a cost function study (Johnes and Johnes 2016).

Figure 5 here

\subsection{Second stage results}

The results of the statistical analysis of the possible determinants of efficiencies are provided in table 3 .

\section{Table 3 here}

In the simplest specification of the second stage model (Model 1) pre- and post-merging institutions are compared with non-merging HEIs. We find that pre-merging HEIs do not differ significantly from non-merging HEIs in terms of efficiency (all else being equal); but that post-merging HEIs have significantly higher efficiency than non-merging HEIs by 0.061 points (or 6 percentage points if we consider efficiency in percentage terms), all else being equal. Merging therefore appears to have positive efficiency effects, even when all other factors underlying efficiency have been taken into account. This might be a consequence of more efficient administrative usage as figure 2 has revealed a slowing of growth in this resource for the sector as a whole over time

Of course, mergers take place at different points in the study period so that the simple comparison potentially conceals differential effects from merging activity over time. In Models 2 to 4 we therefore include post-merging dummies 1 to 4 years after merger. These results reveal that efficiency benefits (significant at the 5\% significance level) from merging occur predominantly in the first year following merger. This is an important finding and one which policy-makers should heed: although a simple merger dummy suggests a positive effect of merger, the more detailed analysis over time points unequivocally to the effects being short-lived.

Quite why this is the case is open to debate and beyond the scope of this paper. One hypothesis arises from the fact that merging activity can attract considerable additional short-term funding from HEFCE: the merger which resulted in the University of Manchester, for example, received $£ 10$ million from HEFCE's Strategic Development Fund (now called the Catalyst Fund) and a further $£ 10$ million in repayable grants. ${ }^{11}$ These funds ${ }^{12}$ may not be expended on higher physical inputs (as used in the efficiency model), rather they may be used to aid rationalization, and hence to lower total inputs in the first instance. However, if rationalisation was followed by restructure this might result in increasing inputs. This would result in the pattern we observe of efficiency rising initially,

\footnotetext{
${ }^{11} \mathrm{See}$ http://www.manchestereveningnews.co.uk/news/greater-manchester-news/universities-get-20m-tohelp-fund-merger-1105150.

${ }^{12}$ Unfortunately the HEFCE Board Papers are not available from HEFCE for the whole of the period under study, and so an in-depth analysis of the role of HEFCE funding is not currently possible.
} 
but not persisting. But this is purely speculative and further work should be carried out to explore all possible reasons as to why the merger benefits appear not to persist.

The main point here, though, is that policy-makers should be wary of adopting merger strategy as a means of promoting efficiency in the long run. In addition, the positive efficiency difference between merging and non-merging HEIs in the years leading to merger, suggesting that universities are not typically using merger as a response to poor performance; in fact merger is typically the choice of universities which are performing well in the run-up to the merger. This is an important point and suggests that any merger policy should not necessarily be targeted at poorly-performing universities.

With regard to HEI type, post-1992 universities are more efficient than colleges of HE by around 0.10 points (or 10 percentage points if we consider efficiency in percentage terms); the former are typically larger than the latter and this might explain this result. Pre-1992 HEIs, in contrast, are less efficient than colleges of HE (but these results, however, are significant only at the $10 \%$ significance level). If we look at the characteristics of the different types of HEIs we find that the biggest difference between the groups is in terms of research and student numbers: post-1992 HEIs are typically the largest in terms of student numbers, while pre-1992 universities have much greater research activity, on average. We therefore hypothesise that the different focus of these universities may explain the differences in performance.

The variable MEDICINE has a surprisingly large positive and significant effect on efficiency (taking into account all other factors), and this is consistent across all four models. It appears therefore that the variable may be picking up a quality rather than a subject mix effect.

The proportion of income derived from government sources (GOVT) has a significant but very small negative effect on efficiency, and this is in line with our expectations and evidence from elsewhere (Wolszczak-Derlacz 2014). HEI size has a negative (but nonlinear) effect on efficiency (all else being equal) over the size range of most of the institutions in the data set. There is therefore no evidence of increasing returns to scale here, which aligns with evidence from Sweden (Daghbashyan 2011), and from cost function studies for the UK, but not with studies based on European HE (WolszczakDerlacz and Parteka 2011; Wolszczak-Derlacz 2014). Given that merger inevitably increases university size this result appears somewhat perverse. There is clearly a tension between being merged (which has a positive effect on efficiency), and being large (which is pulling in the opposite direction). The positive effect of merger is therefore potentially a consequence of returns to scope rather than returns to scale.

Our hypothesis that the composition of the student body might be expected to affect efficiency is not confirmed by the results: the proportion of total students from overseas has no significant effect on efficiency. Thus there is neither evidence of crosssubsidization of research through international students nor of overseas students requiring greater resources.

The year dummies suggest increasing efficiency from 2003/04 onwards relative to the base year 1996/97 - although the years 2008/09 and 2009/10 are exceptions to this pattern 
(that is the significantly higher efficiency in these years relative to the base year is smaller than for the other years) and this is probably due to the shock of the global financial crisis on the sector. Increasing austerity and expansion of the sector over the period from 2003/04 have therefore been accompanied by generally greater efficiency. These might be caused by improving technology which can positively affect both teaching and research production; they may also incorporate changes arising from increasing tuition fees (to a ceiling of $£ 3000$ in $2006 / 07$ and a ceiling of $£ 9000$ in 2012/13 although the latter is unlikely to have any effect on these results).

\subsection{Robustness check}

The problem with an analysis such as this where we use empirical data rather than data from randomised trials is that assignment to the group of merged universities is nonrandom. This can potentially cause selection bias or an endogeneity problem (Gerfin and Lechner 2002), since either the decision to merge (or not to merge) may be caused by several factors which are usually not observed in the empirical data (Caliendo and Kopeinig 2008), or there may be a two-way (endogenous) relationship between efficiency and merger activity, ${ }^{13}$ and these can bias the results. To assess the robustness of the results reported in the previous section we redo the analysis using propensity score matching, a method proposed by (Rosenbaum and Rubin 1983) to reduce the bias in the estimation of treatment effects (here the effect of merger) with empirical data sets.

We find that, comparing the merged HEIs with a sample of non-merged HEIs matched on the basis of characteristics such as type of HEI, size, number of students studying medicine and veterinary sciences and source of funding, the conditional effect of merger on efficiency is significantly higher in the merged than the matched non-merging HEIs. ${ }^{14}$ This confirms the result regarding the merger effect reported in section 5.2.

\section{Conclusions}

This paper reports the results of an empirical analysis of efficiency in English universities over 17 years. We find that mean efficiency for the sector has been around $60 \%$ to $70 \%$ suggesting that there is scope for increasing efficiency in the sector as a whole. The results also confirm previous findings that the efficiency levels of the vast majority of HEIs are not significantly different from each other. In other words, statistically, there is no difference in the performance of most of the HEIs. What is more, the small number of universities which have the lowest performance have specific characteristics (they are small and specialist) which are not captured in the DEA model. Thus their apparent low level of efficiency should be treated with some caution.

A second stage panel data analysis of the efficiency scores suggests that, all else being equal, merger activity has a positive effect on efficiency. Merged HEIs have efficiency

\footnotetext{
${ }^{13}$ Preliminary evidence does not in fact point to a two-way relationship (Johnes and Tsionas 2014).

${ }^{14}$ Full propensity score matching results are available from the authors on request.
} 
which is around 5 percentage points higher post-merger than non-merging HEIs holding all else constant. This result is confirmed using propensity score matching. However, managers and policy-makers should treat this result with great caution: more detailed examination of the effects of merger over time suggests that, while there is apparently a positive efficiency impact of merger, it is short-lived with the effect being greatest (and highly significant) in the first year after merger, tapering off thereafter.

These findings are clearly of interest to policy-makers who may claim that they justify a policy of merger in higher education. Drawing such a hasty conclusion should be avoided for several reasons. First the context of the data analysed (i.e. English higher education which has generally not had a top-down policy of merger in the higher education sector) should be remembered. Thus the merging institutions in this data set have made the decision to merge themselves - it has not been imposed from above, and it is important for higher education managers to recognise this. As such, HEIs which are pre-disposed to merger may have distinct characteristics from those which do not. Indeed, there is some suggestion in the results that HEIs which subsequently merge are actually more efficient (by 2 to 3 percentage points) than those which do not merge. As a consequence, whether or not such results would be forthcoming in a policy-led setting is therefore still open to debate. Second, the results seem to suggest that there are decreasing returns to scale indicating that any positive merger effects are deriving from scope rather than scale. It is therefore important that merging HEIs have complementary operations where opportunities from economies of scope might be most likely. Third, the finding that two or more years after merger there is no significant difference in efficiency between merged and non-merging HEIs suggests that efficiency gains from merger may well be shortlived. Clearly this result requires further work to establish why the effects do not appear to continue into the longer term. 
Table 1 Descriptive statistics of the inputs and outputs of the first stage DEA model

Descriptive Statistics from 1996/1997 to 2012/2013

Number of Observations $=2197$

\begin{tabular}{lrr}
\hline Variable & Mean & Std. Deviation \\
\hline OUTPUTS & & \\
\hline PGOUTPUT & 1142.40 & 1054.48 \\
UGOUTPUT & 2572.94 & 2062.10 \\
\cline { 2 - 3 } & 22942.53 & 50754.13 \\
\hline RESEARCH & \multicolumn{2}{|}{} \\
\hline PGINPUT & 1881.77 & 1647.22 \\
UGIPNPUT & 6853.22 & 5303.32 \\
STAFF & 845.23 & 872.76 \\
ACSERV & 10499.77 & 10182.90 \\
\cline { 2 - 3 } ADMIN & 18872.28 & 16433.89
\end{tabular}

Note: All input and output variables measured in monetary values are deflated to December 2012 values using a consumer price index for the UK economy. Full definitions of the variables are provided in Appendix 1.

Table 2: Descriptive statistics of the explanatory variables of the second stage model

\begin{tabular}{llllll}
\hline Variable & Mean & Std.Deviation & Minimum & Maximum & $\mathrm{N}$ \\
\hline GOVT & 0.413 & 0.130 & 0.000 & 0.842 & 2197 \\
\hline SIZE & 8.732 & 6.661 & 0.026 & 35.86 & 2197 \\
\hline MEDICINE & 0.053 & 0.192 & 0.000 & 1.984 & 2197 \\
\hline OVERSEAS & 0.163 & 0.119 & 0.000 & 0.745 & 2197 \\
\hline
\end{tabular}

Note: See Appendix 2 for definitions of variables 
Table 3: Possible determinants of university efficiency

\begin{tabular}{|c|c|c|c|c|}
\hline \multirow[t]{2}{*}{ Random Effects Model } & \multirow[b]{2}{*}{ Model 1} & \multicolumn{3}{|c|}{ Bootstrapped Pooled DEA CRS Efficiencies } \\
\hline & & Model 2 & Model 3 & Model 4 \\
\hline PREMERGER & $\begin{array}{l}0.029 * \\
(0.013)\end{array}$ & $\begin{array}{l}0.028 * \\
(0.013)\end{array}$ & $\begin{array}{l}0.027 * * \\
(0.013)\end{array}$ & \\
\hline POSTMERGER & $\begin{array}{l}0.061 * * \\
(0.014)\end{array}$ & & & \\
\hline MERGERt-3 & & & & $\begin{array}{l}-0.007 \\
(0.034)\end{array}$ \\
\hline MERGERt-2 & & & & $\begin{array}{l}0.043 \\
(0.031)\end{array}$ \\
\hline MERGERt-1 & & & & $\begin{array}{l}-0.001 \\
(0.029)\end{array}$ \\
\hline MERGERt & & $\begin{array}{l}0.025 \\
(0.038)\end{array}$ & $\begin{array}{l}0.023 \\
(0.038)\end{array}$ & $\begin{array}{l}0.019 \\
(0.038)\end{array}$ \\
\hline MERGERt+1 & & $\begin{array}{l}0.099 * \\
(0.039)\end{array}$ & $\begin{array}{l}0.097 * * \\
(0.039)\end{array}$ & $\begin{array}{l}0.090 * \\
(0.039)\end{array}$ \\
\hline MERGERt+2 & & $\begin{array}{l}0.063 \\
(0.039)\end{array}$ & $\begin{array}{l}0.061 \\
(0.039)\end{array}$ & $\begin{array}{l}0.057 \\
(0.039)\end{array}$ \\
\hline MERGERt+3 & & $\begin{array}{l}0.073 \\
(0.041)\end{array}$ & $\begin{array}{l}0.071 \\
(0.041)\end{array}$ & $\begin{array}{l}0.068 \\
(0.041)\end{array}$ \\
\hline MERGERt+4 & & $\begin{array}{l}0.067 * \\
(0.039)\end{array}$ & $\begin{array}{l}0.066 \\
(0.039)\end{array}$ & \\
\hline MEDICINE & $\begin{array}{l}0.098 * * \\
(0.024)\end{array}$ & $\begin{array}{l}0.104 * * \\
(0.024)\end{array}$ & $\begin{array}{l}0.101 * * \\
(0.024)\end{array}$ & $\begin{array}{l}0.100 * * \\
(0.025)\end{array}$ \\
\hline OVERSEAS & $\begin{array}{l}-0.047 \\
(0.045)\end{array}$ & $\begin{array}{l}-0.030 \\
(0.044)\end{array}$ & $\begin{array}{l}-0.038 \\
(0.045)\end{array}$ & $\begin{array}{l}-0.034 \\
(0.045)\end{array}$ \\
\hline PRE1992 & & $\begin{array}{l}-0.027 \\
(0.014)\end{array}$ & & \\
\hline POST1992 & $\begin{array}{l}0.117 * * \\
(0.017)\end{array}$ & $\begin{array}{l}0.103^{* *} \\
(0.015)\end{array}$ & $\begin{array}{l}0.111 * * \\
(0.017)\end{array}$ & $\begin{array}{l}0.110^{* * *} \\
(0.017)\end{array}$ \\
\hline RUSSELL & $\begin{array}{l}-0.011 \\
(0.023)\end{array}$ & & $\begin{array}{l}-0.006 \\
(0.023)\end{array}$ & $\begin{array}{l}-0006 \\
(0.023)\end{array}$ \\
\hline OTHERPRE1992 & $\begin{array}{l}-0.025 \\
(0.014)\end{array}$ & & $\begin{array}{l}-0.026^{*} \\
(0.014)\end{array}$ & $\begin{array}{l}-0.029 * \\
(0.014)\end{array}$ \\
\hline SIZE & $\begin{array}{l}-0.020 \\
(0.002)\end{array}$ & $\begin{array}{l}-0.019 * * \\
(0.002)\end{array}$ & $\begin{array}{l}-0.020 * * \\
(0.002)\end{array}$ & $\begin{array}{l}-0.020 * * \\
(0.002)\end{array}$ \\
\hline SIZESQ & $\begin{array}{l}0.0004 * * \\
(0.00008)\end{array}$ & $\begin{array}{l}0.0004 * * \\
(0.00008)\end{array}$ & $\begin{array}{l}0.0004 * * \\
(0.00008)\end{array}$ & $\begin{array}{l}0.0004 * * \\
(0.00008)\end{array}$ \\
\hline GOVT & $\begin{array}{l}-0.302 * * \\
(0.049)\end{array}$ & $\begin{array}{l}-0.295 * * \\
(0.049)\end{array}$ & $\begin{array}{l}-0.293 \text { ** } \\
(0.049)\end{array}$ & $\begin{array}{l}-0.288 * * \\
(0.049)\end{array}$ \\
\hline YEAR97/98 & $\begin{array}{l}0.011 \\
(0.024)\end{array}$ & $\begin{array}{l}0.011 \\
(0.024)\end{array}$ & $\begin{array}{l}0.011 \\
(0.024)\end{array}$ & $\begin{array}{l}0.011 \\
(0.024)\end{array}$ \\
\hline YEAR98/99 & $\begin{array}{l}-0.004 \\
(0.024)\end{array}$ & $\begin{array}{l}-0.004 \\
(0.024)\end{array}$ & $\begin{array}{l}-0.004 \\
(0.024)\end{array}$ & $\begin{array}{l}-0.007 \\
(0.024)\end{array}$ \\
\hline YEAR99/00 & $\begin{array}{l}-0.004 \\
(0.024)\end{array}$ & $\begin{array}{l}-0.006 \\
(0.024)\end{array}$ & $\begin{array}{l}-0.006 \\
(0.024)\end{array}$ & $\begin{array}{l}-0.008 \\
(0.024)\end{array}$ \\
\hline YEAR00/01 & $\begin{array}{l}0.036 \\
(0.024)\end{array}$ & $\begin{array}{l}0.035 \\
(0.024)\end{array}$ & $\begin{array}{l}0.035 \\
(0.024)\end{array}$ & $\begin{array}{l}0.033 \\
(0.024)\end{array}$ \\
\hline YEAR01/02 & $\begin{array}{l}0.040 \\
(0.024)\end{array}$ & $\begin{array}{l}0.038 \\
(0.024)\end{array}$ & $\begin{array}{l}0.038 \\
(0.024)\end{array}$ & $\begin{array}{l}0.036 \\
(0.024)\end{array}$ \\
\hline YEAR02/03 & $\begin{array}{l}0.063 * \\
(0.024)\end{array}$ & $\begin{array}{l}0.061^{*} \\
(0.024)\end{array}$ & $\begin{array}{l}0.062 * \\
(0.024)\end{array}$ & $\begin{array}{l}0.059 * * \\
(0.024)\end{array}$ \\
\hline YEAR03/04 & $\begin{array}{l}0.097 * * \\
(0.024)\end{array}$ & $\begin{array}{l}0.097 * * \\
(0.024)\end{array}$ & $\begin{array}{l}0.098 * * \\
(0.024)\end{array}$ & $\begin{array}{l}0.094 * * \\
(0.024)\end{array}$ \\
\hline YEAR04/05 & $\begin{array}{l}0.094 * * \\
(0.024)\end{array}$ & $\begin{array}{l}0.094^{* *} \\
(0.024)\end{array}$ & $\begin{array}{l}0.095 * * \\
(0.024)\end{array}$ & $\begin{array}{l}0.092 * * \\
(0.024)\end{array}$ \\
\hline YEAR05/06 & $\begin{array}{l}0.090 * * \\
(0.025)\end{array}$ & $\begin{array}{l}0.090^{* *} \\
(0.025)\end{array}$ & $\begin{array}{l}0.091 * * \\
(0.025)\end{array}$ & $\begin{array}{l}0.086^{* *} \\
(0.024)\end{array}$ \\
\hline YEAR06/07 & $\begin{array}{l}0.097 * * \\
(0.024)\end{array}$ & $\begin{array}{l}0.098^{* *} \\
(0.024)\end{array}$ & $\begin{array}{l}0.100 * * \\
(0.024)\end{array}$ & $\begin{array}{l}0.094 * * \\
(0.024)\end{array}$ \\
\hline YEAR07/08 & $\begin{array}{l}0.081 \text { ** } \\
(0.025)\end{array}$ & $\begin{array}{l}0.081^{* *} \\
(0.025)\end{array}$ & $\begin{array}{l}0.082 * * \\
(0.025)\end{array}$ & $\begin{array}{l}0.077^{* *} \\
(0.024)\end{array}$ \\
\hline YEAR08/09 & $\begin{array}{l}0.046^{*} \\
(0.025)\end{array}$ & $\begin{array}{l}0.047^{*} \\
(0.025)\end{array}$ & $\begin{array}{l}0.049 * \\
(0.025)\end{array}$ & $\begin{array}{l}0.044 * \\
(0.025)\end{array}$ \\
\hline YEAR09/10 & $\begin{array}{l}0.072 * * \\
(0.025)\end{array}$ & $\begin{array}{l}0.072 * * \\
(0.025)\end{array}$ & $\begin{array}{l}0.075^{* *} \\
(0.025)\end{array}$ & $\begin{array}{l}0.069 * * \\
(0.025)\end{array}$ \\
\hline YEAR10/11 & $\begin{array}{l}0.122^{* *} \\
(0.025)\end{array}$ & $\begin{array}{l}0.123^{* *} \\
(0.025)\end{array}$ & $\begin{array}{l}0.126 * * \\
(0.025)\end{array}$ & $\begin{array}{l}0.121 * * \\
(0.025)\end{array}$ \\
\hline YEAR11/12 & $\begin{array}{l}0.171 * * \\
(0.025)\end{array}$ & $\begin{array}{l}0.173^{* * *} \\
(0.025)\end{array}$ & $\begin{array}{l}0.176^{* * *} \\
(0.025)\end{array}$ & $\begin{array}{l}0.170^{* *} \\
(0.025)\end{array}$ \\
\hline YEAR12/13 & $\begin{array}{l}0.110^{* *} \\
(0.026)\end{array}$ & $\begin{array}{l}0.115^{* *} \\
(0.026)\end{array}$ & $\begin{array}{l}0.117 * * \\
(0.026)\end{array}$ & $\begin{array}{l}0.111^{* *} \\
(0.026)\end{array}$ \\
\hline CONSTANT & $\begin{array}{l}0.810^{* * *} \\
(0.033)\end{array}$ & $\begin{array}{l}0.803^{* *} \\
(0.033)\end{array}$ & $\begin{array}{l}0.804 * * \\
(0.033)\end{array}$ & $\begin{array}{l}0.810^{* *} \\
(0.033)\end{array}$ \\
\hline
\end{tabular}

Note: Standard errors are shown in brackets. * and ** signal that the coefficient is significantly different form zero at the $5 \%$ and $1 \%$ significance level, respectively. 
Figure 1: Mean values of outputs used in the DEA, 1996/97-2012/13

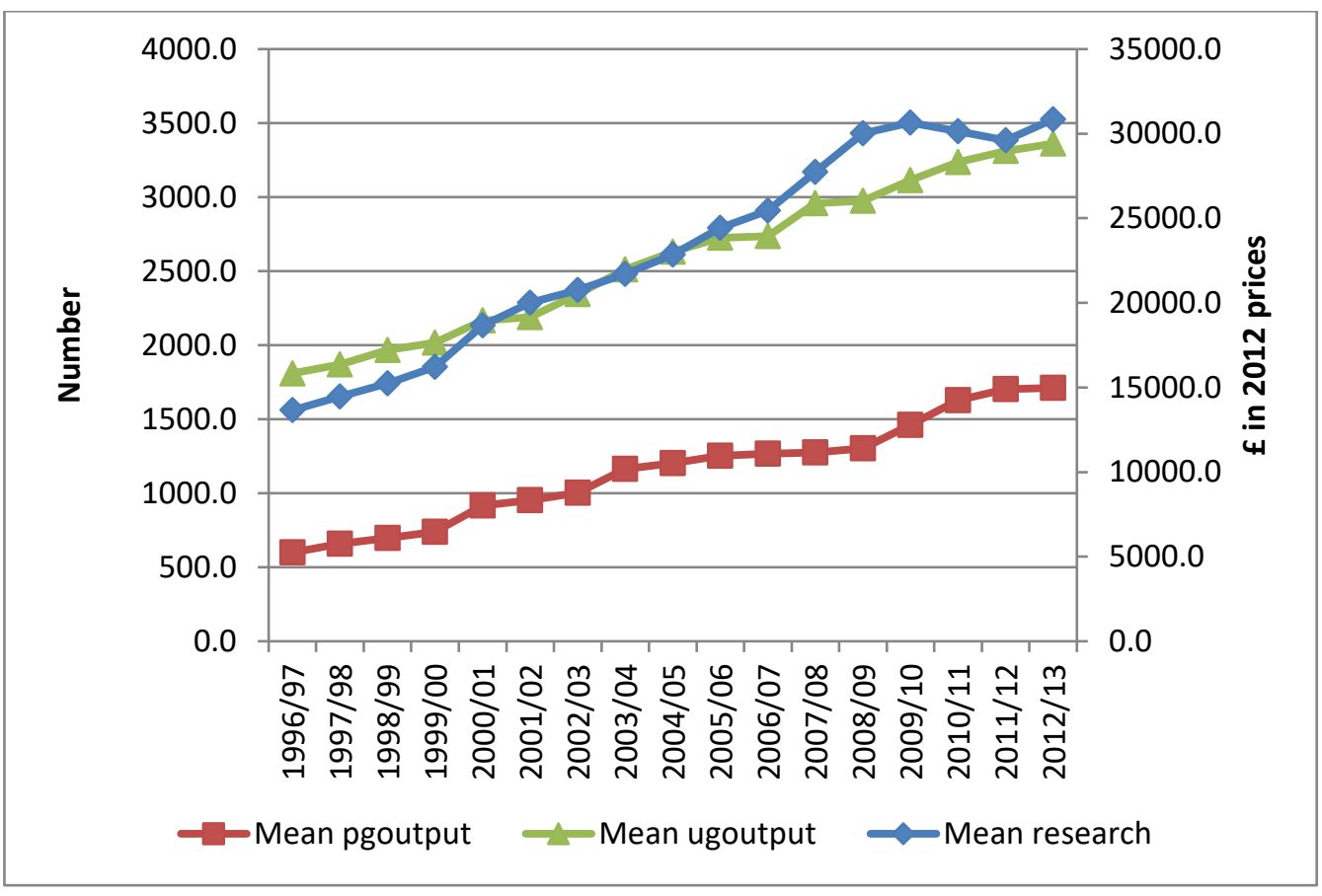

Figure 2: Mean values of inputs used in the DEA, 1996/97-2012/13

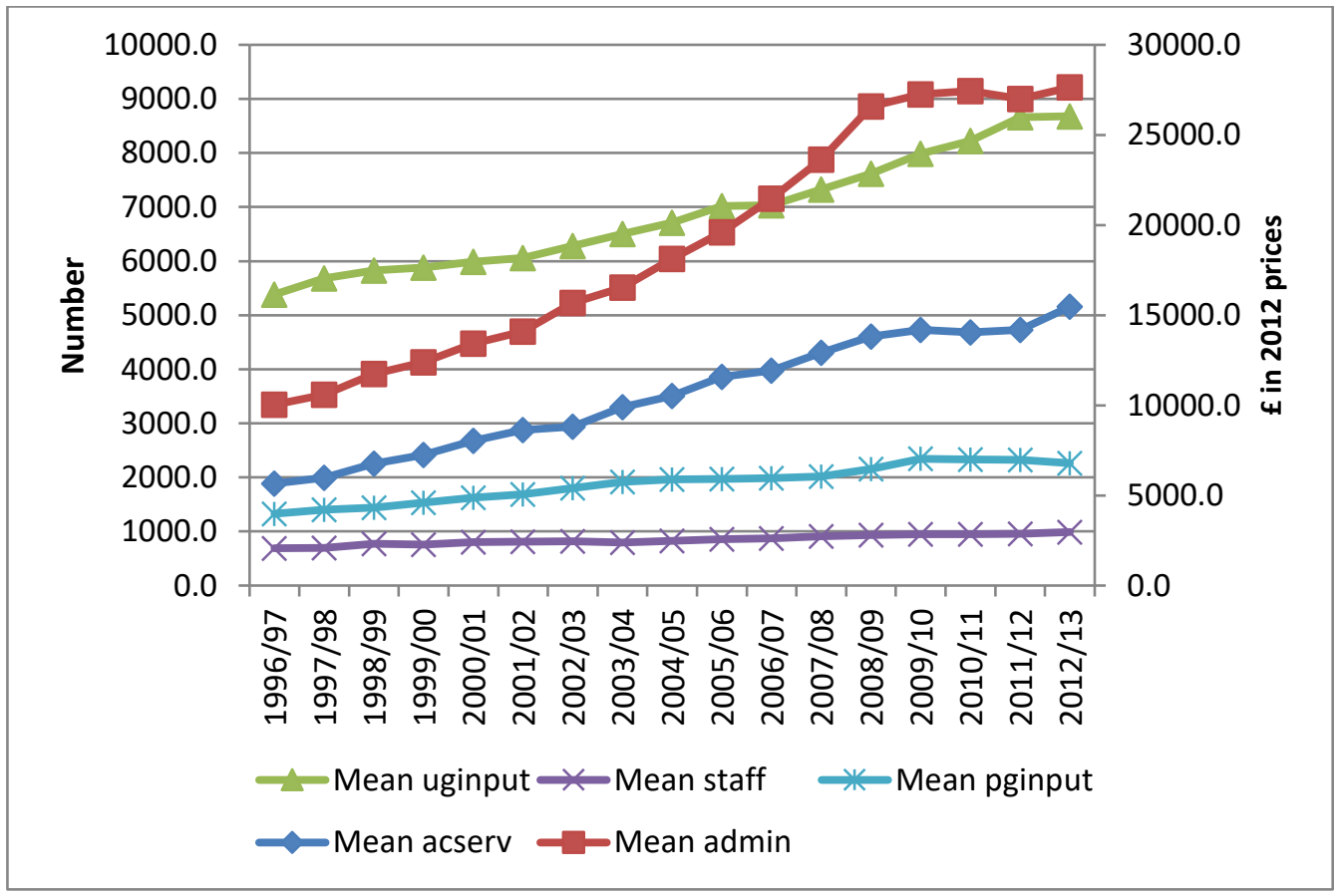


Figure 3: Mean DEA bias-corrected efficiency over time



Figure 4: Histogram of mean HEI efficiencies - Overall technical efficiency

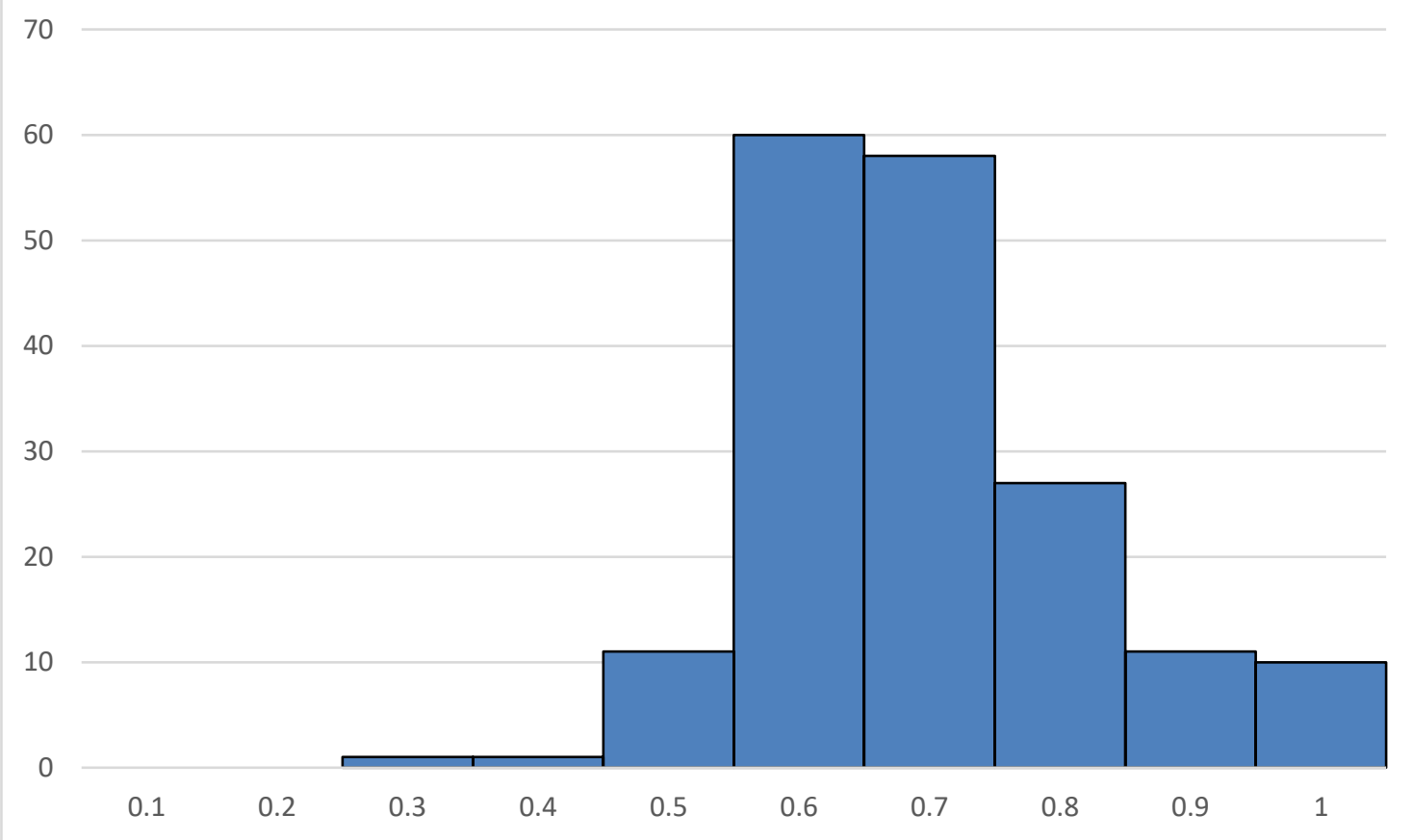


Figure 5: Mean pure technical efficiency score and associated 95 per cent confidence interval by $\mathrm{HEI}$

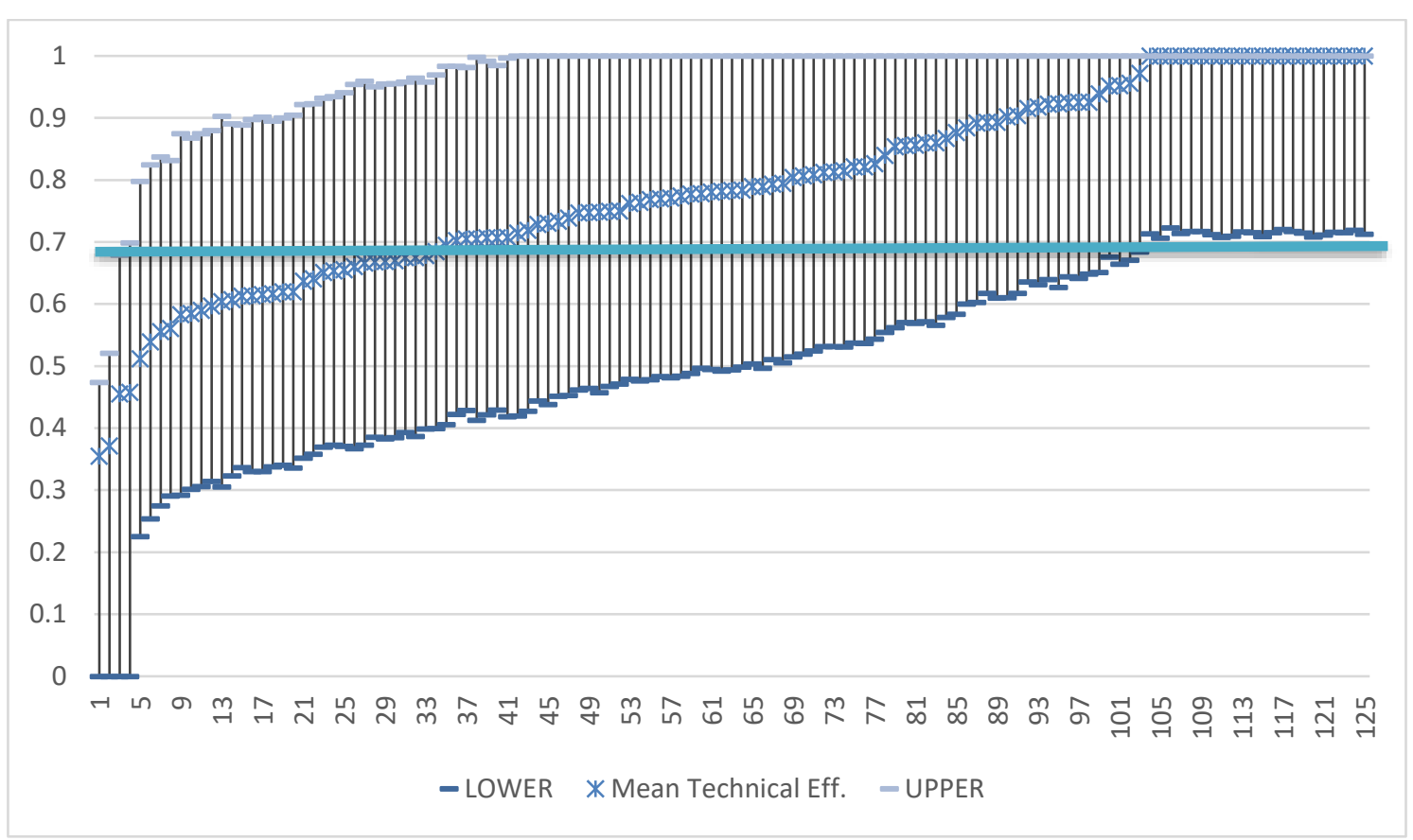


Aarrevaara, T. (2007). 'Enhancing universities in Finland.' Journal of Finance and Management in Colleges and Universities 4: 261-292.

Aarrevaara, T., I. R. Dobson and C. Elander (2009). 'Brave new world: higher education reform in Finland.' Higher Education Management and Policy 21(2): 89-106.

Abbott, M. and H. Doucouliagos (2003). 'The efficiency of Australian universities: a data envelopment analysis.' Economics of Education Review 22: 89-97.

Ahn, T., V. Arnold, A. Charnes and W. W. Cooper (1989). 'DEA and ratio efficiency analyses for public institutions of higher learning in Texas.' Research in Governmental and Nonprofit Accounting 5: 165-185.

Ahn, T. and L. M. Seiford (1993). 'Sensitivity of DEA to models and variable sets in a hypothesis test setting: The efficiency of university operations'. Creative and Innovative Approaches to the Science of Management Y. Ijiri (ed), Quorum Books: pp191-208.

Andersson, C., J. Antelius, J. Månsson and K. Sund (2017). 'Technical efficiency and productivity for higher education institutions in Sweden.' Scandinavian Journal of Educational Research 61(2): 205-223.

Arbuthnott, J. P. and T. R. Bone (1993). 'Anatomy of a merger.' Higher Education Quarterly 47(2): 103-119.

Athanassopulos, A. and E. A. Shale (1997). 'Assessing the comparative efficiency of higher education institutions in the UK by means of data envelopment analysis.' Education Economics 5(2): 117-135.

Aula, H.-M. and J. Tienari (2011). 'Becoming "world-class"? Reputation-building in a university merger.' Critical Perspectives on International Business 7(1): 7-29.

Avkiran, N. K. (2001). 'Investigating technical and scale efficiencies of Australian universities through data envelopment analysis.' Socio-Economic Planning Sciences 35: 57-80.

Baker, S. (2011). 'School of Pharmacy to merge with UCL'. Times Higher Education. 20th July 2011

Beasley, J. E. (1990). 'Comparing university departments.' Omega 18(2): 171-183.

Beasley, J. E. (1995). 'Determining teaching and research efficiencies.' Journal of the Operational Research Society 46(4): 441-452.

Berriman, J. and M. Jacobs (2010) 'In the eye of the storm: Moving from collaboration to consolidation'. Talking Points

Bolli, T. and F. Somogyi (2011). 'Do competitively acquired funds induce universities to increase productivity?' Research Policy 40(1): 136-147.

Bonaccorsi, A., C. Daraio and L. Simar (2006). 'Advanced indicators of productivity of universities: An application of robust nonparametric methods to Italian data.' Scientometrics 66(2): 389-410.

Bösecke, K. (2009). Value Creation in Mergers , Acquisitions, and Alliances. Weisbaden, Springer Gabler.

Boxall, M. and P. Woodgates (2014). Here be dragons: How universities are navigating the uncharted waters of higher education. London, PA Consulting Group.

Breu, T. M. and R. L. Raab (1994). 'Efficiency and perceived quality of the nation's 'Top 25' national universities and national liberal arts colleges: An application of data envelopment analysis to higher education.' Socio-Economic Planning Sciences 28(1): 33-45.

Brown, A. D. and M. Humphreys (2003). 'Epic and tragic tales: Making sense of change.' The Journal of Applied Behavioural Science 39(2): 121-144.

Browne, J. (2010). 'Securing a sustainable future for higher education: An independent review of higher education funding and student finance.' Department for Business, Innovation and Skills, London. 
Cai, Y. and X. Yang (2015). 'Mergers in Chinese higher education: Lessons for studies in a global context.' European Journal of Higher Education 6(1).

Caliendo, M. and S. Kopeinig (2008). 'Some practical guidance for the implication of propensity score matching.' Journal of Economic Surveys 22(1): 31-72.

Cartwright, S., M. Tytherleigh and S. Robertson (2007). 'Are mergers always stressful? Some evidence from the higher education sector.' European Journal of Work and Organizational Psychology 16(4): 456-478.

Chen, D. Y. (2002). 'A study on the amalgamation of Chinese higher education institutions.' Asia Pacific Education Review 3(1): 48-55.

Coelli, T. J., D. S. P. Rao, C. J. O'Donnell and G. E. Battese (2005). An Introduction to Efficiency and Productivity Analysis. New York, Springer.

Cuesta, R. A. and L. Orea (2002). 'Mergers and technical efficiency in Spanish savings banks: A stochastic distance function approach.' Journal of Banking and Finance 26(12): 2231-2247.

Curri, G. (2002). 'Reality versus perception: Restructuring tertiary education and institutional organisational change - a case study ' Higher Education 44(1): 133151.

Daghbashyan, Z. (2011). 'The economic efficiency of Swedish higher education institutions.' CESIS Electronic Working Paper Series No. 245.

Daraio, C., A. Bonaccorsi, A. Geuna, B. Lepori, L. Bach, P. Bogetoft, M. F. Cardoso, E. Castro-Martinez, G. Crespi, I. Fernandez de Lucio, H. O. Fried, A. GarcíaAracil, A. Inzelt, B. Jongbloed, G. Kempkes, P. Llerena, M. Matt, M. A. Olivares, C. Pohl, T. Raty, M. J. Rosa, C. S. Sarrico, L. Simar, S. Slipersaeter, P. N. Teixeira and P. Vanden Eeckaut (2011). 'The European university landscape: A micro characterization based on evidence from the Aquameth project.' Research Policy 40(1): 148-164.

De Fraja, G. and P. Valbonesi (2012). 'The design of the university system.' Journal of Public Economics 96(3-4): 317-330.

De Witte, K. and L. López-Torres (2015). 'Efficiency in education: A review of literature and a way forward.' Journal of the Operational Research Society 68(4): 339-363.

Doyle, J. R., A. J. Arthurs, R. H. Green, L. McAulay, M. R. Pitt, P. A. Bottomley and W. Evans (1996). 'The judge, the model of the judge, and the model of the judged as judge: Analyses of the UK 1992 research assessment exercise data for business and management studies.' Omega 24(1): 13-28.

El-Mahgary, S. and R. Lahdelma (1995). 'Data envelopment analysis: Visualizing the results.' European Journal of Operational Research 83(3): 700-710.

Fielden, J. and L. Markham (1997). 'Learning lessons from mergers in higher education.' CHEMS Paper No 17: 8pp CHEMS Consulting, Hampshire.

Flegg, T. and D. Allen (2007a). 'Does expansion cause congestion? The case of the older British universities, 1994-2004.' Education Economics 15(1): 75-102.

Flegg, T. and D. Allen (2007b). 'Using Cooper's approach to explore the extent of congestion in the New British universities.' Economics Issues 12(2): 47-81.

Flegg, T. and D. Allen (2009). 'Congestion in the new British universities: A further analysis.' Journal of the Operations Research Society of Japan 52(2): 186-203.

Flegg, T., D. Allen, K. Field and T. W. Thurlow (2004). 'Measuring the efficiency of British universities: a multi-period data envelopment analysis.' Education Economics 12(3): 231-249.

Gamage, D. T. (1993). 'The reorganisation of the Australian higher educational institutions towards a unified national system.' Studies in Higher Education 18(1): 81-94.

Gerfin, M. and M. Lechner (2002). 'A microeconometric evaluation of the active labour market policy in Switzerland.' The Economic Journal 112(482): 854-893. 
Glass, J. C., G. McCallion, D. G. McKillop, S. Rasaratnam and K. S. Stringer (2006). 'Implications of variant efficiency measures for policy evaluation in UK higher education.' Socio-Economic Planning Sciences 40: 119-142.

Glass, J. C., D. G. McKillop and N. S. Hyndman (1995a). 'The achievement of scale efficiency in UK universities: a multiple-input multiple-output analysis ' Education Economics 3(3): 249-263.

Glass, J. C., D. G. McKillop and N. S. Hyndman (1995b). 'Efficiency in the provision of university teaching and research: an empirical analysis of UK universities.' Journal of Applied Econometrics 10(1): 61-72.

Green, C. and G. Johnes (2009). 'Economies of scale and mergers in higher education'. The Routledge International Handbook of Higher Education. M. Tight, K.-h. Mok, J. Huisman and C. Morphew (ed). New York, Routledge.

Griffiths, S. (2010). 'Be afraid, parents'. The Sunday TImes. London Retrieved from http://www.timesonline.co.uk/tol/life_and_style/education/article6990896.ece accessed 25th February 2010.

Harman, G. (2000). 'Institutional mergers in Australian higher education since 1960.' Higher Education Quarterly 54(4): 343-366.

Harman, G. and K. Harman (2003). 'Institutional mergers in higher education: Lessons from international experience.' Tertiary Education and Management 9(1): 29-44.

Harman, G. and K. Harman (2008). 'Strategic mergers of strong institutions to enhance competitive advantage.' Higher Education Policy 21(1): 99-121.

Harman, K. (2002). 'Merging divergent campus cultures into coherent educational communities: Challenges for higher education leaders.' Higher Edcuation 44(1): 91-114.

Harman, K. and V. L. Meek (2002). 'Introduction to special issue: Merger revisitied: international perspectives on mergers in higher education.' Higher Education 44(1): $1-4$.

Hatton, E. J. (2002). 'Charles Sturt University: A case study of institutional amalgamation.' Higher Education 44(1): 5-27.

HEFCE (2012). 'Collaborations, alliances and mergers in higher education: Consultation on lessons learned and guidance for institutions.' HEFCE 2012/06 Higher Education Funding Council for England, London.

$\mathrm{Hu}, \mathrm{Y}$. and W. Liang (2008). 'Malmquist index analysis of the dynamic changes in scientific research productivity of some Chinese universities before and after merger.' Frontiers of Education in China 3(3): 429-447.

Izadi, H., G. Johnes, R. Oskrochi and R. Crouchley (2002). 'Stochastic frontier estimation of a CES cost function: the case of higher education in Britain.' Economics of Education Review 21(1): 63-71.

Johnes, G. (1996). 'Multi-product cost functions and the funding of tuition in UK universities.' Applied Economics Letters 3: 557-561.

Johnes, G. (1997). 'Costs and industrial structure in contemporary British higher education.' Economic Journal 107: 727-737.

Johnes, G. (1998). 'The costs of multi-product organisations and the heuristic evaluation of industrial structure.' Socio-Economic Planning Sciences 32(3): 199-209.

Johnes, G. and J. Johnes (1993). 'Measuring the research performance of UK economics departments: an applciation of data envelopment analysis.' Oxford Economic Papers 45: 332-347.

Johnes, G. and J. Johnes (2009). 'Higher education institutions' costs and efficiency: taking the decomposition a further step.' Economics of Education Review 28(1): 107-113.

Johnes, G. and J. Johnes (2016). 'Costs, efficiency and economies of scale and scope in the English higher education sector.' Oxford Review of Economic Policy 32(4): 596-614. 
Johnes, G., J. Johnes and E. Thanassoulis (2008). 'An analysis of costs in institutions of higher education in England.' Studies in Higher Education 33(5): 527-549.

Johnes, G., J. Johnes, E. Thanassoulis, P. Lenton and A. Emrouznejad (2005). An Exploratory Analysis of the Cost Structure of Higher Education in England. London, Department for Education and Skills, Research Report 641.

Johnes, J. (2004). 'Efficiency measurement'. International Handbook on the Economics of Education. G. Johnes and J. Johnes (ed). Cheltenham, Edward Elgar: pp613742.

Johnes, J. (2006). 'Data envelopment analysis and its application to the measurement of efficiency in higher education.' Economics of Education Review 25(3): 273-288.

Johnes, J. (2008). 'Efficiency and productivity change in the English higher education sector from 1996/97 to 2004/05.' The Manchester School 76(6): 653-674.

Johnes, J. (2014). 'Efficiency and mergers in English higher education 1996/97 to 2008/9: Parametric and non-parametric estimation of the multi-input multioutput distance function.' The Manchester School 82(4): 465-487.

Johnes, J. (2015). 'Operational Research in education.' European Journal of Operational Research 243(3): 683-696.

Johnes, J. and G. Johnes (2013). Efficiency in the Higher Education Sector: A Technical Exploration. London, Department for Business Innovation and Skills.

Johnes, J. and M. Tsionas (2014). University mergers in England: Effects on efficiency. European Workshop on Efficiency and Productivity Analysis, 15-18 June Helsinki, Finland.

Johnes, J. and L. Yu (2008). 'Measuring the research performance of Chinese higher education institutions using data envelopment analysis.' China Economic Review 19(4): 679-696.

Jump, P. (2014). 'Cut 50\% of universities and bar undergraduates from Oxbridge'. Times Higher Education. London, Times Supplements Ltd 25th June 2014

Kelchtermans, S. and F. Verboven (2010). 'Program duplication in higher education is not necessarily bad.' Journal of Public Economics 94(5-6): 397-409.

Kjekshus, L. and T. Hagen (2007). 'Do hospital mergers increase hospital efficency? Evidence from a national health service country.' Journal of Health Services Research and Policy 12(4): 230-235.

Kwoka, J. and M. Pollitt (2010). 'Do mergers improve efficiency? Evidence from restructuring the US electric power sector.' International Journal of Industrial Organization 28(6): 645-656.

Kyvik, S. (2002). 'The merger of non-university colleges in Norway.' Higher Education 44(1): 53-72.

Lang, D. (2002). 'A lexicon of inter-institutional cooperation.' Higher Edcuation 44(1): 153-183.

Locke, W. (2007). 'Higher education mergers: Integrating organisational cultures and developming appropriate management styles.' Higher Education Quarterly 61(1): 83-102.

Mandelson, P. (2009). 'Higher Education Funding 2010-11'. Letter to HEFCE Retrieved from http://www.hefce.ac.uk/news/newsarchive/2009/HEFCE,Grant,settlement/ accessed 26th February 2010.

Mao, Y.-q., Y. Du and J.-j. Liu (2009). 'The effects of university mergers in China since 1990s.' International Journal of Educational Management 23(1): 19-33.

Matthews, D. (2011). 'Funding council reaffirms case for Welsh mergers'. Times Higher Education. London, Times Supplements Ltd. 13th July 2011

Mildred, G. (2002). 'Launching the Unified National System: What happened in South Australia.' Higher Edcuation 44(1): 29-51.

Nazarko, J. and J. Šaparauskas (2014). 'Application of DEA method in efficiency evaluation of public higher education institutions.' Technological and Economic Development of Economy 20(1): 25-44. 
Ng, Y. C. and S.-k. Li (2009). 'Efficiency and productivity growth in Chinese universities during the post refirm period.' China Economic Review 20: 183-192.

Ng, Y. C. and S. K. Li (2000). 'Measuring the research performance of Chinese higher education institutions: An application of data envelopment analysis.' Education Economics 8(2): 139-156.

Norgård, J. D. and O.-J. Skodvin (2002). 'The importance of geography and culture in mergers: A Norwegian institutional case study.' Higher Edcuation 44(1): 73-90.

Patterson, G. (2000). 'Findings on economies of scale in higher education: implications for strategies of merger and alliance.' Tertiary Education and Management 6(4): 259-269.

Post, T., L. Cherchye and T. Kuosmanen (2002). 'Nonparametric efficiency estimation in stochastic environments.' Operations Research 50(4): 645-655.

Puusa, A. and J. Kekäle (2013). 'Commitment in the context of a merger.' Tertiary Education and Management 19(3): 205-218.

Ripoll-Soler, C. and M. De-Miguel-Molina (2014). 'Are mergers a win-win strategic model? A content analysis of inter-institutional collaboration between higher education institutions.' Tertiary Education and Management 20(1): 44-56.

Rosenbaum, P. R. and D. B. Rubin (1983). 'The central role of the propensity score in observational studies for causal effects.' Biometrika 70(1): 41-55.

Sav, G. T. (2012). 'Stochastic cost frontier and inefficiency estimates of public and private universities: Does government matter?' International Advances in Economic Research 18(2): 187-198.

Sav, G. T. (2013). 'Effects of financial source dependency on public university operating efficiencies: Data envelopment single-stage and Tobit two-stage evaluations.' Review of Economics and Finance 3(1): 63-73.

Simar, L. and P. W. Wilson (2007). 'Estimation and inference in two-stage, semiparametric models of production processes.' Journal of Econometrics 136(1): 31-64.

Sinuany-Stern, Z., A. Mehrez and A. Barboy (1994). 'Academic departments efficiency via DEA.' Computers and Operations Research 21(5): 543-556.

Skodvin, O.-J. (1999). 'Mergers in higher education - success or failure?' Tertiary Education and Management 5(1): 65-80.

Stewart, G. (2003). 'College mergers: Lessons to be learned from other sectors.' Research in Post-Compulsory Education 8(3): 305-328.

Teixeira, P. N. (2007). 'Waiting for the tide to change? Strategies for survival of Portuguese private HEIs.' Higher Education Quarterly 61(2): 208-222.

Thanassoulis, E., K. De Witte, J. Johnes, G. Johnes, G. Karagiannis and M. C. Portela (2016). 'Applications of Data Envelopment Analysis in Education'. Data Envelopment Analysis: A Handbook of Empirical Studies and Applications. J. Zhu (ed). New York, Spinger-Verlag.

Thanassoulis, E., M. Kortelainen, G. Johnes and J. Johnes (2011). 'Costs and efficiency of higher education institutions in England: A DEA analysis.' Journal of the Operational Research Society 62(7): 1282-1297.

Tight, M. (2011). 'How many universities are there in the United Kingdom? How many should there be?' Higher Edcuation 62(5): 649-663.

Tomkins, C. and R. Green (1988). 'An experiment in the use of data envelopment analysis for evaluating the efficiency of UK university departments of accounting.' Financial Accountability and Management 4(2): 147-164.

van Vuuren, M., P. Beelan and M. D. T. de Jong (2010). 'Speaking of dominance, status differences, and identification: Making sense of a merger.' Journal of Occupational and Prganizational Psychology 83(3): 627-643.

Wan, Y. and M. W. Peterson (2007). 'A case study of a merger in Chinese higher education: the motives, processes and outcomes.' International Journal of Educational Development 27(6): 683-696. 
Wolszczak-Derlacz, J. (2014). 'An evaluation and explanation of (in)efficiency in higher education institutions in Europe and the U.S. with the application of two-stage semi-parametric DEA.' IRLE Working Paper No. 114-14, http://irle.berkeley.edu/workingpapers/114-14.pdf.

Wolszczak-Derlacz, J. and A. Parteka (2011). 'Efficiency of European public higher education institutions: A two-stage multi-country approach.' Scientometrics 89(3): 887-917.

Worthington, A. C. (2001). 'An empirical survey of frontier efficiency measurement techniques in education.' Education Economics 9(3): 245-268. 
Appendix 1: Definitions of variables included in the DEA

\begin{tabular}{|c|c|}
\hline Variable Name & \\
\hline Inputs & Definition \\
\hline PGINPUT & $\begin{array}{l}\text { The total number of FTE postgraduate students (i.e. students on } \\
\text { programmes of study leading to higher degrees, diplomas and } \\
\text { certificates, including Postgraduate Certificate of Education } \\
\text { (PGCE) and professional qualifications) }\end{array}$ \\
\hline UGINPUT & $\begin{array}{l}\text { The total number of FTE first degree and other undergraduates. } \\
\text { The 'other undergraduates' category includes qualification aims } \\
\text { below degree level such as Foundation Degrees and Higher } \\
\text { National Diploma (HND) }\end{array}$ \\
\hline STAFF & $\begin{array}{l}\text { The number of full-time academic staff plus } 0.5 \text { times the number } \\
\text { of part-time academic staff }\end{array}$ \\
\hline ACSERV & $\begin{array}{l}\text { Expenditure incurred on centralized academic services such as the } \\
\text { library and learning resource centres, central computer and } \\
\text { computer networks, centrally run museums, galleries and } \\
\text { observatories, and any other general academic services (in } £ 000 \mathrm{~s} \text { ) }\end{array}$ \\
\hline ADMIN & $\begin{array}{l}\text { Expenditure on total administration and central services including } \\
\text { expenditure on staff and student facilities (including, for example, } \\
\text { careers Advisory Service, all grants to student societies, } \\
\text { emoluments to wardens of halls of residence, accommodation } \\
\text { office, athletic and } \\
\text { sporting facilities, excluding maintenance, and the institution's } \\
\text { health service) and general educational expenditure (in } £ 000 s \text { ) }\end{array}$ \\
\hline Outputs & Definition \\
\hline PGOUTPUT & $\begin{array}{l}\text { The number of higher degrees plus total other postgraduate } \\
\text { qualifications awarded (including doctorate, other higher degrees, } \\
\text { PGCEs and other postgraduate qualifications) }\end{array}$ \\
\hline RESEARCH & Income received from research grants and contracts (in £000s) \\
\hline UGOUTPUT & $\begin{array}{l}\text { The number of first degree and other undergraduate degrees } \\
\text { awarded (see definition of UGINPUT) }\end{array}$ \\
\hline
\end{tabular}

Source: HESA, Students in Higher Education, various volumes; HESA, Finances of Higher

Education Providers, various volumes (formerly Resources of Higher Education Institutions);

Note that ACSERV, ADMIN and RESEARCH are deflated to December 2012 values using the consumer price index from OEDC data (OECD.StatExtracts) (an organization for economic cooperation and development), since the HE pay and prices index for UK universities no longer provides an index specific to HE costs and prices:

http://stats.oecd.org/index.aspx?querytype=view\&queryname $=221 \#$ 
Appendix 2: Definitions of variables included in the second stage analysis

\begin{tabular}{ll}
\hline Variable Name & Definition \\
\hline PREMERGER & Dummy variable for HEIs before being merged \\
\hline POSTMERGER & Dummy variable signifying HEI which have been merged \\
\hline MERGERt-f & $\begin{array}{l}\text { Dummy variable (equal to 1) capturing the effect of mergers up to f } \\
\text { periods before the year of merger f=(1,...,3) }\end{array}$ \\
\hline MERGERt & $\begin{array}{l}\text { Dummy variable (equal to 1) capturing the effect of merger in the year } \\
\text { that merger has been realized }\end{array}$ \\
\hline MERGERt+g & $\begin{array}{l}\text { Dummy variable (equal to 1) capturing the effect of mergers up to g } \\
\text { periods ahead after the year of merger g=(1....4) }\end{array}$ \\
\hline RIZE & $\begin{array}{l}\text { Ratio of students aligned to medicine and veterinary studies to total FTE } \\
\text { students (i.e. PGINPUT+UGINPUT) }\end{array}$ \\
\hline OVERSEAS & $\begin{array}{l}\text { Total FTE students (i.e. PGINPUT+UGINPUT) divided by 1000 } \\
\text { Total number of overseas students divided by total number of FTE } \\
\text { students (i.e. PGINPUT+UGINPUT) }\end{array}$ \\
\hline Traditional HEIs including Oxford and Cambridge, and universities \\
established in the 1960s
\end{tabular}

Source: HESA, Students in Higher Education, various volumes; HESA, Finances of Higher Education Providers, various volumes (formerly Resources of Higher Education Institutions); 